
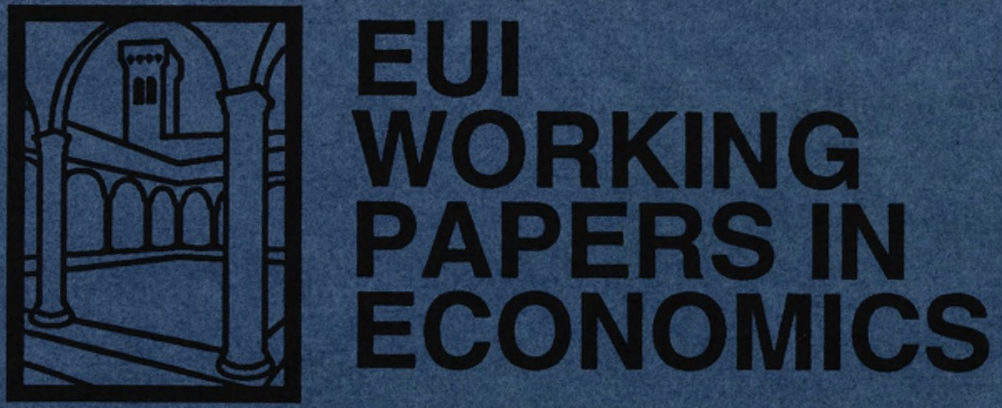

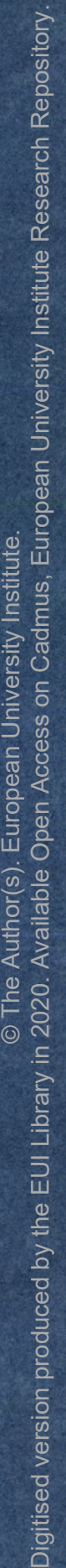

European University Institute, Florence 


\section{EUROPEAN UNIVERSITY INSTITUTE}

|| || ||||| || || || || || || || || || ||| || || |||||||||||||||| 


\section{EUROPEAN UNIVERSITY INSTITUTE, FLORENCE}

\section{ECONOMICS DEPARTMENT}

EUI Working Paper ECO No. 95/25

On the Limits and Possibilities of the Principle of Minimum Differentiation

JEROEN HINLOOPEN

and

CHARLES VAN MARREWIJK

\section{WP 330 \\ EUR}

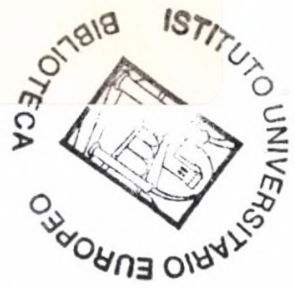

BADIA FIESOLANA, SAN DOMENICO (FI) 
All rights reserved.

No part of this paper may be reproduced in any form without permission of the authors.

(C) Jeroen Hinloopen and Charles van Marrewijk

Printed in Italy in July 1995

European University Institute

Badia Fiesolana

I - 50016 San Domenico (FI)

Italy 


\title{
On the Limits and Possibilities of the Principle of Minimum Differentiation*
}

\author{
by \\ JEROEN HINLOOPEN \\ European University Institute \\ and \\ CHARLES VAN MARREWIJK \\ Erasmus University Rotterdam
}

\begin{abstract}
Analyzing the consequences of a finite reservation price in Hotelling's classic location model by using pure strategies in prices and locations, we show that firms will never be further apart than half the length of the market and never closer together than one quarter if they cover the entire market (i.e. compete) at the symmetric equilibrium location.
\end{abstract}

We would like to thank, without implicating, Dan Kovenock, Stephen Martin, Louis Phlips, Jacques Thisse, Bauke Visser and workshop participants at the European University Institute and the Tinbergen Institute for stimulating conversations and useful comments and suggestions. 


\section{INTRODUCTION}

In his influential article 'Stability in Competition' Hotelling (1929) studies spatial duopolistic competition in a two-stage, non-cooperative game in which firms first choose locations and then are invoived in Bertrand price competition. Hotelling argued that both firms will locate in the centre of the market, such that "buyers are confronted everywhere with an excessive sameness" (p.54). The celebrated 'Principle of Minimum Differentiation' was born. There was, however, a flaw in Hotelling's reasoning, as pointed out independently by Vickrey (1964) and d'Aspremont, Gabszewicz and Thisse (1979; henceforth AGT). The 'equilibrium' price on which Hotelling's argument was built is not a Nash-Cournot equilibrium price if firms are located too closely together, because then they have an incentive to undercut the opponent and capture the entire market. Once undercutting is profitable no pure strategy Nash-Cournot equilibrium in prices exists (see AGT). ${ }^{1}$

One crucial assumption of Hotelling, that each consumer purchases one unit irrespective of price, was already questioned by Lerner and Singer (1937). If taken literally the assumption of an infinite reservation price implies there is no upper limit to a consumer's expenditure. Lerner and Singer argue: "It is necessary, therefore, to assume an upper limit to the price each consumer is willing to pay for his unit of commodity if we are going to be at all realistic."12 Economides (1984) analyzes some of the implications of

${ }^{1}$ There is a remarkable, mystical footnote in Hotelling (1929, pp. 51-52) referring to the possibility of undercutting as "an adventitious feature of our problem" which is "necessary for simplicity," arguing that "in general we should consider $\mathrm{q}_{1}$ and $\mathrm{q}_{2}$ as continuous functions of $\mathrm{p}_{1}$ and $\mathrm{p}_{2}$." An adequate rebuttal to this loose claim of Hotelling is in d'Aspremont, Gabszewicz and Thisse (1983), who show, under quite general circumstances, that if firms locate too closely together either i) profits go to zero, or ii) a Nash equilibrium in prices does not exist. Either possibility questions the Principle of Minimum Differentiation.

${ }^{2}$ In discussing the assumptions of the Hotelling model Phlips and Thisse (1982) first mention a 'reservation price' (p. 3). In Hotelling (1929) this reservation price is then infinite. One question this paper will answer is how high the reservation price should be in order to have no effect on the pure price strategies. Incidentally, Lerner and Singer do not study a two-stage game, but a game (that has no Nash-Cournot equilibrium) in which firms simultaneously set prices and locations. 
a finite reservation price within the two-stage Hotelling model. His analysis is incomplete, however, since he restricts attention in the second stage game to locations for which some consumers at the corner of the market are not served. As a result firms either (i) want to relocate in the first stage of the game (moving away from each other), or (ii) are able to form local monopolies. The latter situation, in which the market is large enough for the two firms not to compete at all with each other and earn monopoly profits, is arguably the least interesting possibility.

We analyze the consequences for both price and location of introducing a finite reservation price in the two-stage Hotelling model. In addition to completing Economides's (1984) analysis for symmetric locations we identify four more cases of interest in which firms actually compete with one another, one sub-case of which coincides with the Hotelling analysis of AGT. For the four new cases, we derive the limits and possibilities of the Principle of Minimum Differentiation as a function of the length of the market relative to the effective reservation price. In particular, we show that firms will never be further apart than half the length of the market and never closer together than one quarter.

\section{THE MODEL}

We analyze a two-stage game of complete information. In the first stage firms simultaneously choose location. At the second stage they compete in prices. The Nash-Cournot equilibrium in locations in the first stage of the game is based on the payoffs that are Nash-Cournot equilibrium payoffs of the second stage price game (subgame perfection).

Consumers are uniformly distributed along a line of length $l$ ('main street or a transcontinental railroad'). There are two firms, $a$ and $b$. Firm $a$ is located $h_{a}$ units from the left end of the market and charges price $p_{a}$. Similarly, firm $b$ is located $h_{b}$ units from the right end of the market and charges price $p_{b}$. Transport costs are linear and equal to $t$ for each unit of distance. Each consumer purchases at most one unit of the commodity and has a 
reservation price $v$ beyond which all income is used for an outside good (Salop (1979)). Since consumers bear the cost of transportation (free-on-board mill pricing), a consumer located at point $y$ of the market will not purchase the good if the delivered price of both firms exceeds the reservation price, i.e. if $\min \left\{p_{a}+t\left|y-h_{a}\right|, p_{b}+t\left|y-h_{b}\right|\right\}>v$. Otherwise, this consumer will purchase from firm $a$ if $p_{a}+t\left|y-h_{a}\right|>p_{b}+t\left|y-h_{b}\right|$, and from firm $b$ if this inequality is reversed.

There are three parameters of interest in the above specification, namely $v$ (the reservation price), $t$ (the transportation cost), and $l$ (the length of the market). A little inspection reveals that only the relative position between these variables is important. Therefore, we parameterize the model such that $l=\alpha v / t$, and investigate what happens if $\alpha$ varies. The parameter $\alpha$ is thus the size of the market relative to the effective reservation price $(v / t)$, and can be interpreted as an indicator of the equilibrium intensity of rivalry (in a sense supplementary to the Lerner index or the price-cost margin). The theoretical rationale for this claim is threefold.

First, for given values of $v$ and $l$, two monopolies arise if the cost of transportation $t$ is high. Intuitively this is clear. If it is relatively costly for a consumer to switch from one supplier to another, a firm does not experience fierce competition. On the other hand, if transportation costs go to zero, all firms compete with each other on the basis of the price they quote (perfect competition).

Second, if the market is large, relative to $v$ and $t$, there is room for two monopolies while for relatively small markets firms are in competition whith each other for the same consumers. To put it differently: if the market is large there is a wide dispersion in demand while consumers prefer similar products if the market shrinks.

Third, if the reservation price increases, relative to $l$ and $t$, demand becomes more and more inelastic. In terms of profitability this market becomes more attractive to enter and rivalry will be more intensive. On the other hand, in case of low reservation prices only a few consumers are willing to buy the product and no competition is experienced from other firms. 
More formally, we will investigate equilibria, such that $h_{a}, h_{b} \in[0, l / 2]$. The strategy set of player $i$ in the second stage is $S_{i}=\left\{p_{i} \mid 0 \leq p_{i} \leq v\right\}$ for $i=a, b$. Per unit production costs are constant and equal to zero without loss of generality. Therefore, the payoff function of player $i$ in the second stage is

$$
\pi_{i}\left(p_{a}, p_{b} ; h_{a}, h_{b}\right)=p_{i} D_{i}\left(p_{a}, p_{b} ; h_{a}, h_{b}\right)
$$

where $D_{i}$ is player $i$ 's contingent demand. For any pair $\left(h_{a}, h_{b}\right)$ and any $p_{j}$ we denote by $P_{i}\left(p_{j}, h_{a}, h_{b}\right)$ the set $\operatorname{argmax}_{p_{i}} \pi_{i}\left(p_{a}, p_{b} ; h_{a}, h_{b}\right)$ whenever it is non-empty (player $i$ 's best reply correspondence). A Nash-Cournot Price Equilibrium of the second stage game is a pair of strategies $\left(p_{a}^{*}\left(h_{a}, h_{b}\right), p_{b}^{*}\left(h_{a}, h_{b}\right)\right)$ such that $p_{i}{ }^{*}\left(h_{a}, h_{b}\right) \in P_{i}\left(p_{j}^{*}\left(h_{a}, h_{b}\right)\right)$, for $i, j=a, b, i \neq j$. (Bertrand or price competition). Let $P^{*}\left(h_{a}, h_{b}\right)$ be the set of price equilibria and let $E$ be the subset of pairs $\left(h_{a}, h_{b}\right)$ for which $P^{*}\left(h_{a}, h_{b}\right)$ is non-empty. For any pair $\left(h_{a}, h_{b}\right) \in E$ define $\pi_{i}^{*}\left(h_{a}, h_{b}\right) \equiv \pi_{i}\left(p_{a}^{*}\left(h_{a}, h_{b}\right), p_{b}^{*}\left(h_{a}, h_{b}\right) ; h_{a}, h_{b}\right) .^{3} \quad$ Within this set we denote by $H_{i}\left(h_{j}\right)$ the set $\operatorname{argmax}_{h_{i}} \pi_{i}^{*}\left(h_{a}, h_{b}\right)$ if non-empty. A Nash-Cournot Location Equilibrium of the first stage game is a pair $\left(h_{a}^{*}, h_{b}^{*}\right)$ such that $h_{i}^{*} \in H_{i}\left(h_{j}\right)$, for $i, j=a, b, i \neq j$. This equilibrium is symmetric if $h_{a}^{*}=h_{b}^{*}$. Note that we confine our analysis to pure strategies.

The equilibrium concept builds on AGT (1983) and is similar to Friedman (1988), who reluctantly uses the term 'partial subgame perfection' in this context. See section 8 below for a discussion.

For simplicity we restrict attention to local symmetric Nash-Cournot (henceforth N-C) location equilibria. In particular, given $\epsilon>0$, define $B\left(h_{i} ; \epsilon\right)$ as the closed $\epsilon$-ball around $h_{i}$. Then, for all $\left(h_{a}, h_{b}\right) \in E$ denote by $H_{i}\left(h_{j} ; \epsilon\right)$ the set $\operatorname{argmax}_{h_{i} \in B\left(h_{j} ; \epsilon\right)} \pi_{i}^{*}\left(h_{a}, h_{b}\right) .{ }^{4}$ A Local Symmetric $N-C$ Location Equilibrium is a pair $\left(h_{a}^{*}, h_{b}^{*}\right)$ for which $\exists \epsilon>0$ such that $h_{i}^{*} \in H_{i}\left(h_{j} ; \epsilon\right)$, for $\boldsymbol{i}=\boldsymbol{a}, \boldsymbol{b}, \boldsymbol{i} \neq \boldsymbol{j}$. Clearly the set of symmetric N-C location equilibria is a subset of the set of local symmetric N-C location equilibria. Since in all cases below

\footnotetext{
${ }^{3}$ Implicitly we assume $p_{i}{ }^{*}(\cdot)$ to be uniquely defined (see also footnote 6).

${ }^{4}$ Recall that $h_{a}$ is defined in terms of distance to the left side of the market while $h_{b}$ is defined in terms of the distance to the right side of the market.
} 
in which the two firms actually compete with each other $(\alpha \leq 2)$ there exists only one local symmetric $\mathrm{N}-\mathrm{C}$ location equilibrium, our procedure identifies the unique symmetric N-C location equilibrium if it exists. ${ }^{5}$ If the market is large enough to sustain two monopolists $(\alpha \geq 2)$, our procedure identifies all symmetric N-C location equilibria.

Our methodology in the sequel is as follows. For all possible locations of firm $a$ in the second stage price game, $h_{a} \in[0, l / 2]$, we determine the price equilibrium, if it exists, in the neighbourhood of $h_{a}=h_{b}$. Substituting these prices in the payoff functions gives the Nash equilibrium payoffs of the second stage subgame $\pi_{i}^{*}\left(h_{a}, h_{b}\right)$. We then determine the value of $\partial \pi_{i}^{*}\left(h_{a}, h_{b}\right) / \partial h_{i}$, $i=a, b$, for $h_{a}=h_{b}$, taking appropriate left-hand or right-hand limits if needed. If the derivative is positive (negative) firms have an incentive to move closer to (away from) each other. A local symmetric N-C location equilibrium is reached if either (i) the derivative is zero, (ii) the left-hand limit is positive and the right-hand limit is negative, or (iii) the left-hand limit is positive and the right hand limit is not defined (because no N-C equilibrium price exists if firms move closer to each other). ${ }^{6}$

\section{CASE 1; TWO MONOPOLIES: THE ECONOMIDES CASE $(\boldsymbol{\alpha} \geq 2)$}

We start our analysis by investigating a large market. In fact, the market will be so large relative to the effective reservation price $v / t$, that the two firms will not compete with one another in the $\mathrm{N}-\mathrm{C}$ location equilibrium and earn (maximum) monopoly profits.

For relatively small values of $h_{a}$ the firms are so far away from each other in the large market that they form local monopolies. If we define

\footnotetext{
${ }^{5}$ Since we restrict the location strategy set of player $a$ to be to the left of the centre of the market and that of player $b$ to be to the right of the centre of the market, the symmetric location equilibrium is unique. Enlarging the location strategy sets of both players to the entire market obviously leads to two symmetric location equilibria, where one is the mirror image of the other.

${ }^{6}$ Note that these conditions also apply for player $b$ since its location is measured from the right-end of the market.
} 
Figure 1 Profits, Given Location, for a Monopolist

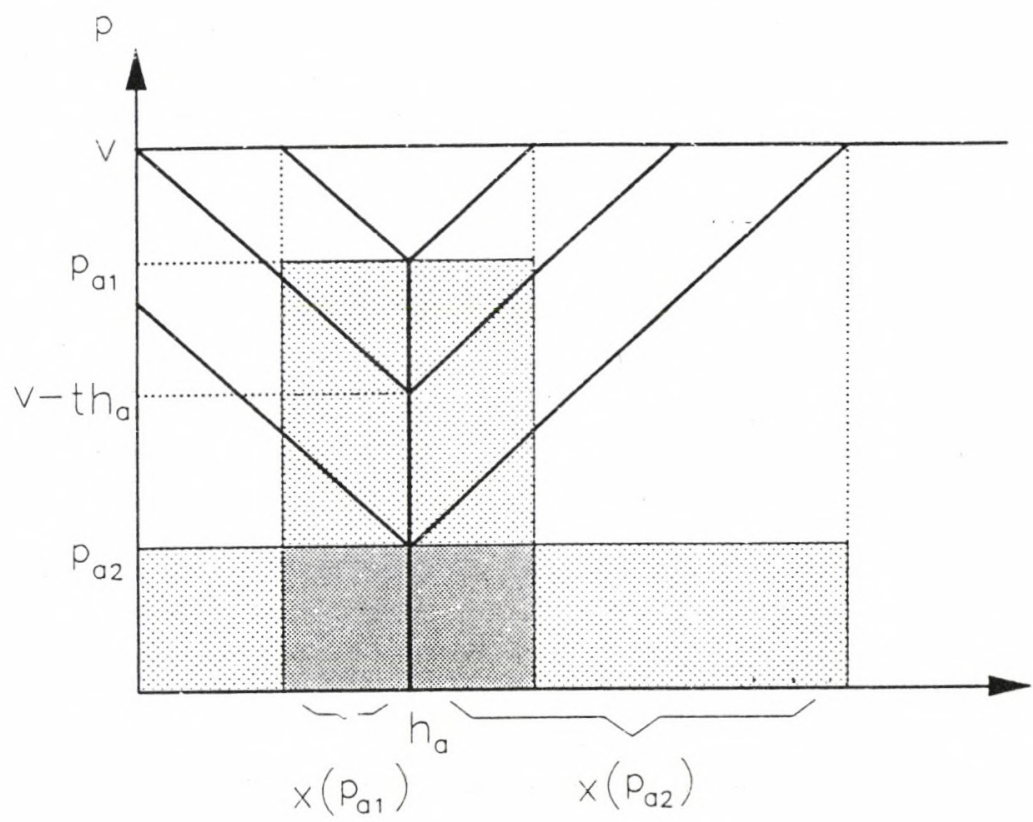

$x(p) \equiv(v-p) / t$ then, if firm $a$ is a local monopolist located at point $h_{a}$ $\left(0 \leq h_{a} \leq l / 2-v / 2 t\right.$, see below) its profits are given by (see Figure 1)

$$
\pi_{a}=\begin{array}{ll}
2 p_{a} x\left(p_{a}\right), & \max \left\{0, v-t h_{a}\right\} \leq p_{a} \leq v \\
p_{a}\left[h_{a}+x\left(p_{a}\right)\right], & 0 \leq p_{a} \leq \max \left\{0, v-t h_{a}\right\}
\end{array}
$$

Profit maximization is then straightforward and leads to prices and profits 


$$
\begin{aligned}
& \frac{1}{2}\left(v+t h_{c}\right), 0 \leq h_{c} \leq \frac{v}{3 t} \\
& p_{a}=v-t h_{a}, \quad \frac{v}{3 t} \leq h_{a} \leq \frac{v}{2 t} \\
& \frac{v}{2}, \quad \frac{v}{2 t} \leq h_{a} \leq \frac{l}{2}-\frac{v}{2^{\prime} t} \\
& \frac{1}{4}\left(v+t h_{a}\right)\left(h_{a}+\frac{v}{t}\right), 0 \leq h_{a} \leq \frac{v}{3 t} ; \quad \frac{\partial \pi_{a}^{*}}{\partial h_{a}}>0 \\
& \pi_{a}^{*}=2\left(v-t h_{a}\right) h_{a}, \quad \frac{v}{3 t} \leq h_{a} \leq \frac{v}{2 t} ; \quad \frac{\partial \pi_{a}^{*}}{\partial h_{a}}>0 \\
& \frac{v^{2}}{2 t}, \\
& \frac{v}{2 t} \leq h_{a} \leq \frac{l}{2}-\frac{v}{2 t} ; \frac{\partial \pi_{a}^{*}}{\partial h_{a}}=0
\end{aligned}
$$

Equation (4) shows that $\partial \pi_{a}^{*}\left(h_{a}, h_{b}\right) / \partial h_{a}>0$ for $h_{a}<v / 2 t$, implying that profits are maximized if the firm is at least $v / 2 t$ away from the end of the market. The total length of the market covered by a firm is then $v / t$ and the price charged equals $v / 2$. Since there are two firms, both these firms can earn monopoly profits if, and only if, the market is large enough, i.e. iff $l \geq 2 v / t$. This is equivalent to $\alpha \geq 2$, the case under investigation in this section.

The above discussion also shows that a conflict between the two firms arises if they get too close together and start encroaching on each other's consumers. More precisely, if the distance between the two firms, $d$ say, is smaller than $v / t$. If so, some consumers at the corners of the market are not served. This situation has been analyzed by Economides (1984). He shows that (i) if firms are fairly close to each other $(6 v / 7 t \leq d<v / t$ there is a 'touching' equilibrium (with price $=v-t d / 2$ ), (ii) if firms get closer $\left(\alpha^{*} v / t \leq d \leq 6 v / 7 t\right.$; where $\left.\alpha^{*} \approx 0.263\right)$ there is a 'competitive' equilibrium 
(with price $=0.4 v+0.2 t d)$, and (iii) if firms get 'too close' $\left(d<\alpha^{*} v / t\right)$ a $\mathrm{N}-\mathrm{C}$ price equilibrium no longer exists. ${ }^{6}$ Economides also shows that under situations (i) and (ii) firms have an incentive to move away from each other in the first stage of the game, indicating that these situations are not N-C location equilibria.

Figure 2 illustrates our results for large markets in case $\alpha$ equals 3 . It depicts firm $a$ 's N-C price equilibrium strategy $p_{a}^{*}$ as a function of firm $a$ 's location $h_{a}\left(0 \leq h_{a}<l / 2\right)$ for symmetric locations of the two firms $\left(h_{a}=h_{b}\right)$, if it exists. Some illustrative delivered prices are also drawn. The picture of the market could be completed with regard to firm $b$ 's N-C price strategy by putting a mirror at the point $l / 2$. The continuum of symmetric $\mathrm{N}-\mathrm{C}$ location equilibria are $h_{a}^{*}=h_{b}^{*} \in[v / 2 t, l / 2-v / 2 t]$, with concomitant price $v / 2$. Note that $h_{a}^{*}$ follows from the first 'definition' of a local N-C location equilibrium. For Figure 2, where $\alpha$ equals 3, this translates to $h_{a}^{*}=h_{b}^{*} \in[v / 2 t, v / t]$ and pure strategy prices equilibrium defined up to $h_{a}=l / 2-\alpha^{*} v / t \approx 1.369 v / t$.

\section{CASE 2; PROFIT MAXIMIZING CLUSTER POINT $(4 / 3 \leq \alpha \leq 2)$}

Suppose that the size of the market shrinks relative to the effective reservation price, i.e. $\alpha$ falls, in the analysis of section 3. This reflects either (i) a shrinkage of the length of the market $l$, (ii) a fall in transportation costs $t$, (iii) a rise in the reservation price $v$, or (iv) an appropriate combination of (i)-(iii). ${ }^{7}$

An inspection of Figure 2 reveals that as $\alpha$ falls the range $h_{a}^{*}$ starts to shrink. Once $\alpha$ is smaller than 2 this range disappears, which might suggest that $h_{a}^{*}$ disappears. Indeed, Economides $(1984$, p. 366$)$ claims that:

\footnotetext{
${ }^{6}$ As is well known, see AGT, the latter situation arises once it is profitable for a firm to undercut its opponent. The precise value of $\alpha^{*}$ is determined by $1 / \alpha^{*}=(7+5 \sqrt{10}) / 6$ (see Economides (1984 p. 357) and appendix A). Moreover, for the 'touching' equilibrium we follow Economides by selecting identical $\mathrm{N}-\mathrm{C}$ equilibrium prices (see also appendix B).
}

\footnotetext{
${ }^{7}$ As already observed, a lower $\alpha$ can be associated with a more competitive market.
} 
Figure 2 Two Monopolies: the Economides Case, $\alpha=3 \in[2, \infty)$

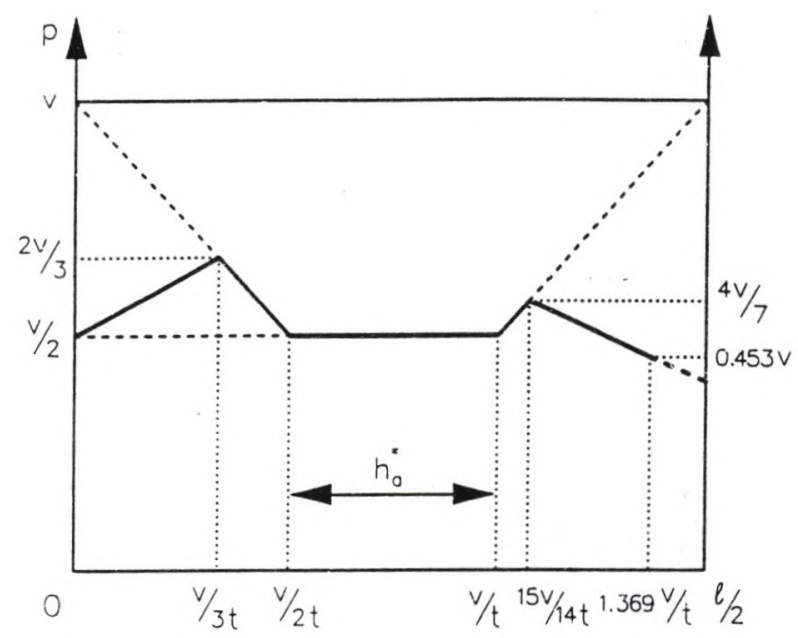

Figure 3 Profit Maximization: Clustering at the market quarters, $\alpha=19 / 10 \in[4 / 3,2]$

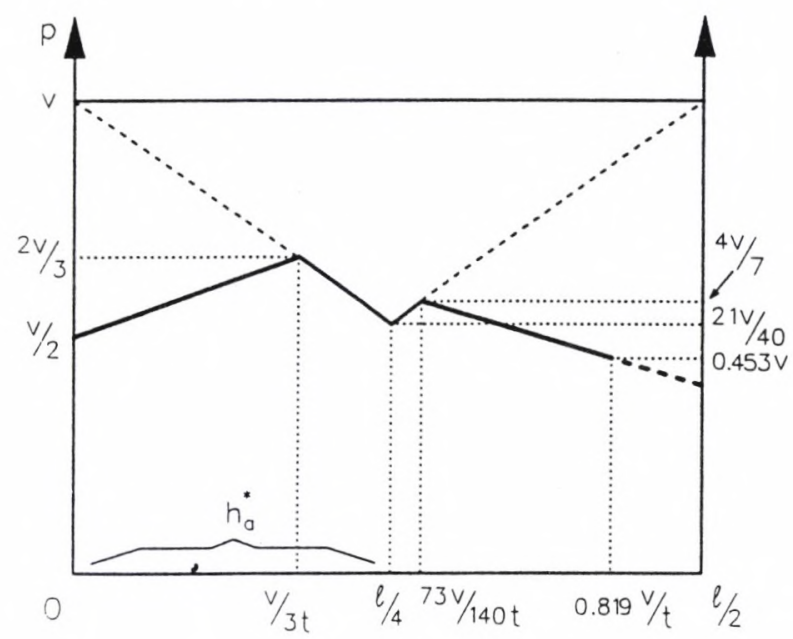


A Nash equilibrium of the varieties game exists if the reservation price is not-too-high.... The essential reason for this result is that, for relatively not-too-high reservation prices, firms are not guaranteed the purchases of the consumers who are located near the edges of the market.

This suggestion, that a $\mathrm{N}-\mathrm{C}$ location equilibrium only exists if some consumers in the corner of the market are not served, is not true. In what follows we show that $h_{a}^{*}$ is also defined when both firms together cover the entire market.

For small values of $h_{a}$ the optimal price strategy determined in Section 3 in the absence of a competitor still holds, because firms still do not encroach on each other's customers. As shown in Section 3 firms then have an incentive to move closer to each other.

For the case under investigation in this section $(4 / 3 \leq \alpha \leq 2)$ the first conflict between the two producers always arises if the distance between the firms is half the market $\left(h_{a}=l / 4\right)$, because the two firms together cover the entire market if $h_{a} \geq l / 4 .^{8}$

If the distance between the two firms is small enough Economides's analysis still holds such that there will be some consumers in the corners of the market who are not served and firms want to move away from each other.

In the intermediate range, if Economides's analysis does not hold and $h_{a}$ is larger than $l / 4$, the $\mathrm{N}-\mathrm{C}$ equilibrium price equals $v-t h_{a}$. This is discussed in more detail in the next section (see in particular footnote 10), which also shows that $\partial \pi_{a}^{*}\left(h_{a}, h_{b}\right) / \partial h_{a}<0$ for the configuration of this section, i.e. firms have an incentive to move away from each other. As a consequence, the $\mathrm{N}-\mathrm{C}$ location equilibrium occurs at the market quarters, $h_{a}^{*}=l / 4$. Note that $h_{a}^{*}$ follows from the second 'definition' of a local N-C

${ }^{8}$ If $\alpha<4 / 3$ the two firms together can cover the entire market for $h_{a}<l / 4$. This situation is analyzed in the next sections. 
location equilibrium. The discussion is summarized in equation (5) with respect to $\mathrm{N}-\mathrm{C}$ equilibrium prices, and is illustrated for $\alpha=19 / 10$ in Figure 3. Note that for this value of $\alpha$ it becomes profitable to undercut if the distance between the two firms is smaller than $\alpha^{*} v / t$ or if $h_{a}^{*} \geq 0.819 v / t$.

$$
\begin{array}{ll}
\frac{1}{2}\left(v+t h_{a}\right), & 0 \leq h_{a} \leq \frac{v}{3 t} \\
v-t h_{a}, & \frac{v}{3 t} \leq h_{a} \leq l / 4
\end{array}
$$

$$
\text { For } \frac{6+13 \alpha^{*}}{5} \leq \alpha \leq 2
$$

$$
\begin{array}{ll}
v-t\left(\frac{l}{2}-h_{a}\right), & \frac{l}{4} \leq h_{a} \leq \frac{l}{2}-\frac{3 v}{7 t} \\
\frac{2}{3}\left[v+t\left(\frac{l}{2}-h_{a}\right)\right], & \frac{l}{2}-\frac{3 v}{7 t} \leq h_{a} \leq \frac{1}{2}\left(l-\alpha^{*} \frac{v}{t}\right)
\end{array}
$$

(5)

$$
\begin{aligned}
& p_{a}=\quad \text { For } \frac{12}{7} \leq \alpha \leq \frac{6+13 \alpha^{*}}{5} \\
& v-t\left(\frac{l}{2}-h_{a}\right), \quad \frac{l}{4} \leq h_{a} \leq \frac{l}{2}-\frac{3 v}{7 t} \\
& \frac{2}{5}\left[v+t\left(\frac{l}{2}-h_{a}\right)\right], \quad \frac{l}{2}-\frac{3 v}{7 t} \leq h_{a} \leq \beta(\alpha) \frac{v}{t}
\end{aligned}
$$

$$
\text { For } \frac{4}{3} \leq \alpha \leq \frac{12}{7}
$$

$$
\begin{array}{ll}
v-t h_{a}, & \frac{v}{3 t} \leq h_{a} \leq v-\frac{t l}{3} \\
\frac{2}{5}\left[v+t\left(\frac{l}{2}-h_{a}\right)\right], & v-\frac{t l}{3} \leq h_{a} \leq \beta(\alpha) \frac{v}{t}
\end{array}
$$


A few points are worth noting. First, when analyzing the 'undercutting' condition that determines how close firms can get for a $\mathrm{N}-\mathrm{C}$ equilibrium price to exist, Economides implicitly assumes that the undercutting firm can sell $2 x\left(p_{u}\right)$ if it charges undercutting price $p_{u}$. However, if the size of the market is small enough this is not possible because then $h_{a}<x\left(p_{u}\right)$. This limits the profitability of undercutting and affects the range over which pure strategy N-C equilibrium prices are defined (see equation (5)). ${ }^{9}$ Second, the competitive forces that drive firms apart, and the extent of the market forces that foster conglomeration, together result in an unique equilibrium location at the market quarters, $h_{a}^{*}=l / 4$, with concomitant price $p^{*}=(1-\alpha / 4) v$. This could be referred to as the 'Principle of Intermediate Differentiation', which is efficient in minimizing transportation cost and maximizing the sum of consumers' and producers' surplus. Third, the range of locations over which Economides's analysis is valid for a given value of $\alpha$ vanishes exactly at $\alpha=4 / 3$. For the smaller market sizes (relative to the effective reservation price) considered in the sequel of this paper an 'Economides Range' no longer exists.

\section{CASE 3; GETTING CLOSE $(8 / 7 \leq \alpha \leq 4 / 3)$}

If the size of the market falls slightly below that of the analysis of Section 4 above, the first conflict of interest between the two firms arises when $h_{a}$ is in the first quarter (namely at $h_{a}=l-v / t$; the point at which the two firms together just cover the entire market). From that point on up to $h_{a}=l / 4$ the $\mathrm{N}-\mathrm{C}$ equilibrium price equals $v-t\left(l / 2-h_{a}\right)$, as illustrated in Figure 4. The analysis of this situation, which mimics the analysis of $h_{a} \in[l / 4, l / 2)$ below, is delegated to appendix B. In this appendix it is also shown that $\partial \pi_{a}^{*}\left(h_{a}, h_{b}\right) / \partial h_{a}>0$ at $h_{a}=h_{b}<l / 4$, i.e. firms have an incentive to move closer to each other.

\footnotetext{
${ }^{9}$ See appendix A for the analysis.
} 
Figure 4 Nash-Cournot Equilibrium Prices I

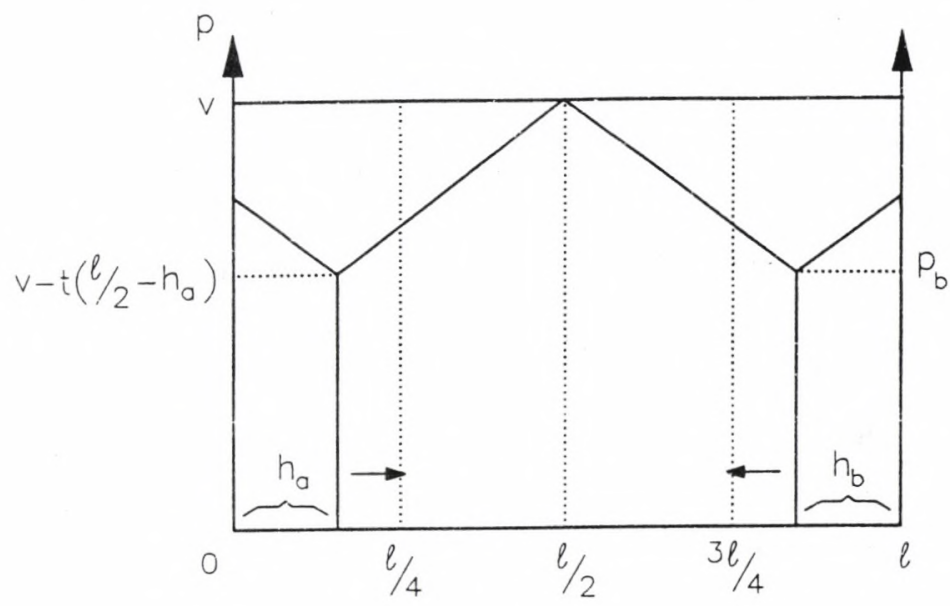

Figure 5 Nash-Cournot Equilibrium Prices II

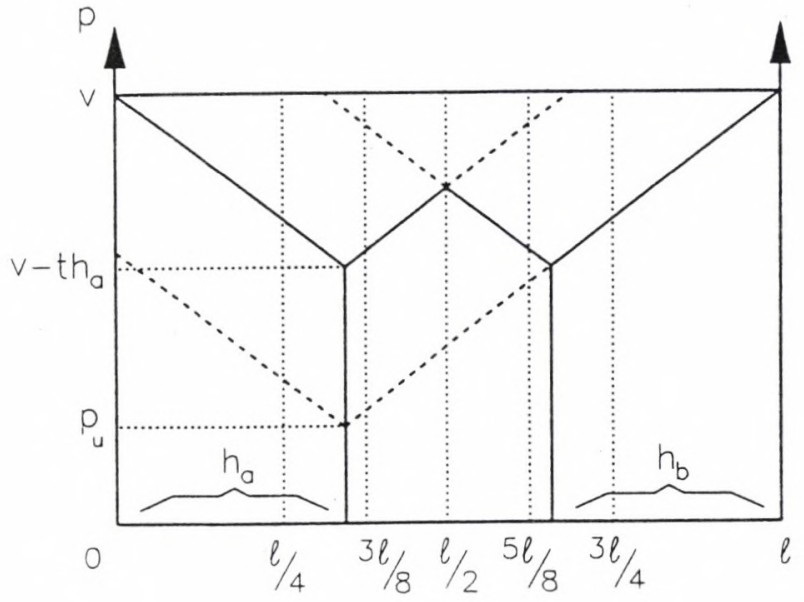


Suppose that $h_{a}, h_{b} \in[l / 4, l / 2)$. We want to show under which conditions prices $p_{a}=v-t h_{a}$ and $p_{b}=v-t h_{b}$ are $\mathrm{N}-\mathrm{C}$ equilibrium prices (in the neighbourhood of symmetric locations). ${ }^{10}$ This situation, which is crucial for an understanding of the influence of reservation prices on the $\mathrm{N}-\mathrm{C}$ price and location equilibria in the Hotelling model, is illustrated in Figure 5. First note, however, that if these are $\mathrm{N}-\mathrm{C}$ equilibrium prices the resulting profits for firm $a$ and $b$ respectively are $\pi_{a}^{*}\left(h_{a}, h_{b}\right)=\left(v-t h_{a}\right)\left(l / 2+h_{a}-h_{b}\right)$ and $\pi_{b}^{*}\left(h_{a}, h_{b}\right)=\left(v-t h_{b}\right)\left(l / 2+h_{b}-h_{a}\right)$. From these it is straightforward to derive that, $\partial \pi_{a}^{*}\left(h_{a}, h_{b}\right) / \partial h_{a}=\partial \pi_{b}^{*}\left(h_{a}, h_{b}\right) / \partial h_{b}=0$ if, and only if, $h_{a}^{*}=h_{b}^{*}=v / t-l / 2$. We will show that for the range of $\alpha$ under consideration in this section $(8 / 7 \leq \alpha \leq 4 / 3)$ the local symmetric $\mathrm{N}-\mathrm{C}$ equilibrium location is indeed at $h_{a}^{*}=v / t-l / 2$. Note that $h_{a}^{*}$ follows from the first 'definition' of a local N-C location equilibrium.

We proceed by examining if a firm has an incentive to increase prices by charging price $\boldsymbol{v}-\boldsymbol{t} \boldsymbol{h}_{a}+\epsilon$, where $\epsilon>0$. Quoting this price leads io profits $\pi_{a}^{+}=\left(v-t h_{a}+\epsilon\right)\left[\left(h_{a}-\epsilon / t\right)+\left(l-h_{a}-h_{b}\right) / 2-\epsilon / t\right] .$. Observe now that if price $v-t h_{a}$ is charged profits are $\pi_{a}=\left(v-t h_{a}\right)\left(l / 2+h_{a}-h_{b}\right)$. The condition $\pi_{a}-\pi_{a}^{+} \geq 0$ implies $h_{a} \leq v / t-l / 3\left(^{*}\right)$, for symmetric locations. " Likewise, define $\pi_{a}^{-}=\left(v-t h_{a}-\epsilon\right)\left[\left(h_{a}+\epsilon / 2 t\right)+\left(l-h_{a}-h_{b}\right) / 2\right]$ as the profits firm $a$ would get if it were to lower its price by $\epsilon>0$ (but $\epsilon$ 'small', i.e. not large enough to undercut once's rival, see below). For symmetric locations the condition $\pi_{a}-\pi_{a}^{-} \geq 0$ results in $h_{a} \geq v / t-l(* *)$. Note that the conditional N-C equilibrium location derived in the preceding paragraph, $h_{a}^{*}=h_{b}^{*}=v / t-l / 2$, falls in the range spanned by $(*)$ and $(* *)$. Two points remain to be resolved.

${ }^{10}$ At these prices the profit curve is 'kinked'.

11 If $\alpha \geq 12 / 7$ the two conditions $h_{a} \leq v / t-l / 3$ and $h_{a} \geq l / 4$ cannot be fulfilleci simultaneously such that for values of $\alpha$ larger than $12 / 7$ the analysis here does not apply (see subcases 2.1 and 2.2 in the previous section). For smaller values of $\alpha$ (but larger than $4 / 5$, see the analysis on undercutting below) the analysis does apply. The condition $h_{a}=v / t-l / 3$ then indicates transition to the Economides analysis (see subcase 2.3 in the previous section), or is irrelevant due to the profitability of undercutting (this section and the next section). 
First, $h_{a}^{*}$ must be larger than $l / 4$ for the analysis to hold, which translates into $\alpha \leq 4 / 3$. Second, we have to examine the possibility of undercutting (which will translate into $\alpha 28 / 7$ ).

To determine the range of locations for which a $\mathrm{N}-\mathrm{C}$ equilibrium price, as depicted in Figure 5, is defined for a given value of $\alpha$ for symmetric locations $h_{a} \geq l / 4$, we examine how close the firms can locate together before it is profitable to undercut the opponent. In the absence of undercutting, the $\mathrm{N}-\mathrm{C}$ equilibrium price and resulting second stage profits equal $p_{a}=v-t h_{a}$, and $\pi_{a}=\left(v-t h_{a}\right) l / 2$. The undercutting price $p_{u}$ follows from $p_{u}+2 t h_{a}=v-t h_{a}$ , which results in profits $\pi_{u}=p_{u} l=\left(v-t l+t h_{a}\right) l$, because an undercutting firm always captures the entire market (see Figure 5). It follows that $\pi_{a}=\pi_{u}$ if $h_{a}=2 l / 3-v / 3 t$. Therefore, N-C equilibrium prices are defined for $h_{a} \leq 2 l / 3-v / 3 t$ . As a consequence, the rule $h_{a}^{*}=v / t-l / 2$ determines the local symmetric $\mathrm{N}-\mathrm{C}$ equilibrium locations up to the point where it is profitable to undercut your opponent, i.e. up to $v / t-l / 2=2 l / 3-v / 3 t$, which is equivalent to $\alpha=8 / 7$. Furthermore, if the undercutting rule $h_{a}=2 l / 3-v / 3 t$ is equated with $l / 4$ it follows that the situation depicted in Figure 5 holds for $\alpha \geq 4 / 5$ (see the next section).

The basic consequence of introducing a reservation price in the Hotelling model is to lower the prices charged by the competing firms. Indeed, if the reservation price is infinite (or 'sufficiently high', see Section 7 below) AGT show that the N-C equilibrium price for symmetric locations equals $t l$, if it exists. For the range of $\alpha$ under consideration in this section $(8 / 7 \leq \alpha \leq 4 / 3$ ) setting the price equal to $t l=\alpha v$ results in a price which exceeds the reservation price, such that firms would not sell anything. Hence the intro 
Figure 6 Nash-Cournot Location Beyond the Market Quarters, $\alpha=7,6 \in[8 / 7,4 / 3]$

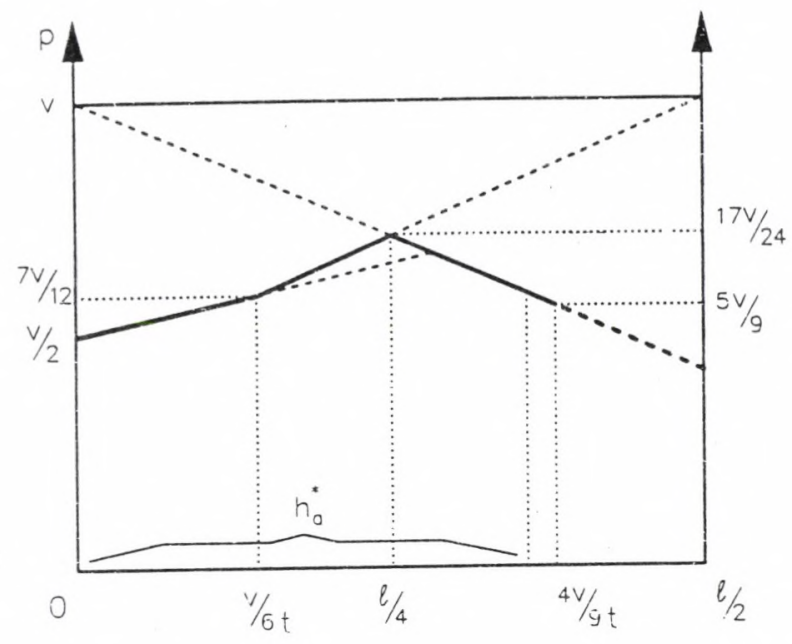

duction of a reservation price substantially lowers the prices charged in the market, which makes it much less attractive to undercut the rival. ${ }^{12}$ Consequently, N-C equilibrium prices are defined beyond the quarters. In an, ultimately vain, effort to capture market share firms have an incentive to move closer together, which strengthens the competition between the two firms and lowers prices. The limit of the Principle of Minimum Differen-

${ }^{12}$ In fact, at the N-C equilibrium location of this section the $\mathrm{N}-\mathrm{C}$ equilibrium price $=$ $\alpha v / 2=t l / 2$, exactly half the Hotelling price. 
tiation is reached when $\alpha=8 / 7$, which results in $h_{a}^{*}=3 l / 8$ and a minimum location equilibrium distance between the two firms of $l / 4(=5 l / 8-3 l / 8)$. For smaller values of $\alpha$ the threat of price wars from undercutting will push the firms back to the quarters, as the next two sections will show. On the other hand, for all values of $\alpha$ exceeding $8 / 7$ the local symmetric $\mathrm{N}-\mathrm{C}$ location equilibrium is determined by profit maximization considerations, not by the threat of price wars.

The N-C equilibrium price for given locations is given in equation 6 . The 'getting close' case is illustrated for $\alpha$ equal to $7 / 6$ in Figure 6, which implies $l-v t=v / 6 t$ and $2 l / 3-v / 3 t=4 v / 9 t$.

$$
\begin{gathered}
\frac{1}{2}\left(v+t h_{a}\right), \quad 0 \leq h_{a} \leq l-\frac{v}{t} \\
p_{a}=v+t\left(h_{a}-\frac{l}{2}\right), l-\frac{v}{t} \leq h_{a} \leq \frac{l}{4} \\
v-t h_{a}, \quad \frac{l}{4} \leq h_{a} \leq \frac{2 l}{3}-\frac{v}{3 t}
\end{gathered}
$$

\section{CASE 4; LIVING ON THE EDGE: THE THREAT OF WAR $(4 / 5 \leq \alpha \leq 8 / 7$}

The analysis in this section can be very brief because it is almost identical to that of the previous section. Two important points should be noted. First, if $\alpha$ is smaller than 1 the two firms always compete with one another and cover the entire market, even if dispersion is at its maximum $\left(h_{a}=h_{b}=0\right)$. Consequently, for such values of $\alpha$ (small markets, or large effective reservation prices) firms are never local monopolists. Second, for all values 
of $\alpha$ smaller than $8 / 7$ we have $\partial \pi_{a}^{*}\left(h_{a}, h_{b}\right) / \partial h_{a}>0$ at $h_{a}=h_{b}$ over the entire range of locations for which $\mathrm{N}-\mathrm{C}$ equilibrium prices are defined. Therefore, the local symmetric $\mathrm{N}-\mathrm{C}$ ' location equilibrium is at this 'edge', i.e. determined by the undercutting rule. The equilibrium location, $h_{a}^{*}$, thus follows from the third 'definition' of a local N-C location equilibrium. The threat of an undercutting price war keeps firms from moving closer together. For the range under consideration in this section $(\alpha \in[4 / 5,8 / 7])$ this translates into $h_{a}^{*}=2 l / 3-v / 3 t=1 / 3[2-1 / \alpha] l$, with concomitant price $p^{*}=2(2-\alpha) v / 3$. For completeness, the $\mathrm{N}-\mathrm{C}$ equilibrium price for arbitrary symmetric locations is given in equation 7 .

$$
p_{a}=\begin{aligned}
& v+t\left(h_{a}-\frac{l}{2}\right), l-\frac{v}{t} \leq h_{a} \leq \frac{l}{4} \\
& v-t h_{a}, \quad \frac{l}{4} \leq h_{a} \leq \frac{2 l}{3}-\frac{v}{3 t}
\end{aligned}
$$

$$
\begin{gathered}
\frac{1}{2}\left(v+t h_{a}\right), \quad 0 \leq h_{a} \leq l-\frac{v}{t} \\
p_{a}=v+t\left(h_{a}-\frac{l}{2}\right), \quad l-\frac{v}{t} \leq h_{a} \leq \frac{l}{4} \\
v-t h_{a}, \quad \frac{l}{4} \leq h_{a} \leq \frac{2 l}{3}-\frac{v}{3 t}
\end{gathered}
$$

\section{CASE 5; MAKING A STAND: HOTELLING $(0 \leq \alpha \leq 4 / 5)$}

The analysis in this section can be as brief as that of the previous section. First, note that for $\alpha \in[2 / 3,4 / 5]$ the symmetric location $h_{a}=3 l / 2-v / t$, derived in appendix $\mathrm{B}$, marks the transition of the $\mathrm{N}-\mathrm{C}$ equilibrium price strategy $p_{a}=v-t\left(l / 2-h_{a}\right)$ for $h_{a} \leq 3 l / 2-v / t$ (depicted in Figure 4), to the 
Figure 7 Hotelling: Living on the Edge, $\alpha=3 / 5 \in[0,2 / 3]$

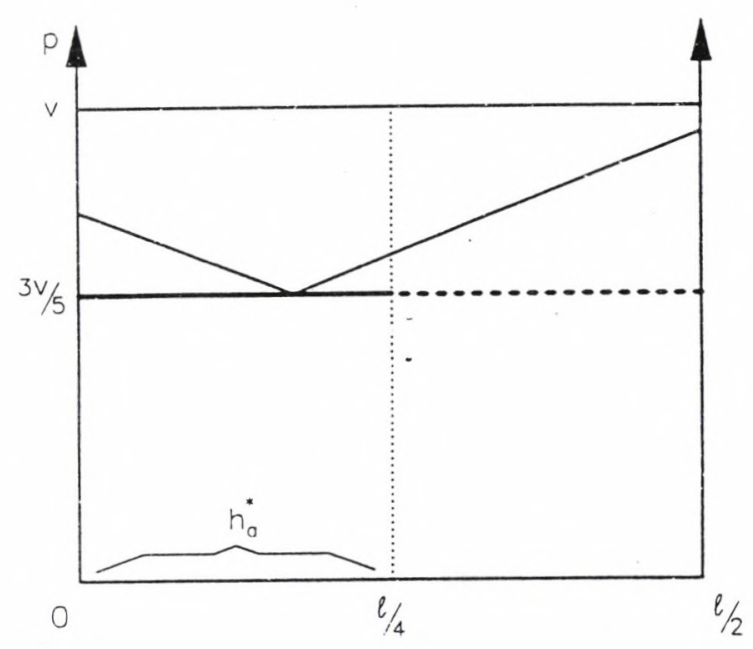

$\mathrm{N}-\mathrm{C}$ equilibrium price strategy $p_{a}=t l$ for $h_{a} \geq 3 l / 2-v / t$ derived by Hotelling. AGT show that the Hotelling price strategy is defined up to the market quarters, such that the local symmetric $\mathrm{N}-\mathrm{C}$ location equilibrium occurs at the quarters, with concomitant $\mathrm{N}-\mathrm{C}$ equilibrium price $t l$. Second, note that for values of $\alpha$ below $2 / 3$ the range of locations with the $\mathrm{N}-\mathrm{C}$ equilibrium price strategy depicted in Figure 4 disappears. Thus, the Hotelling analysis as derived by AGT holds for a 'sufficiently high' reservation price. More precisely, a reservation price $v$ that drives $\alpha=t l / v$ below $2 / 3$, for given values of the length of the market $l$ and transportation costs $t$. This case is the 'pure' Hotelling model and is illustrated in Figure 7. Equation 8 gives' the $\mathrm{N}-\mathrm{C}$ equilibrium prices in the range of $\alpha$ analyzed in this section $(\alpha \leq 4 / 5)$. 


$$
p_{a}=\begin{array}{lll}
v-t\left(\frac{l}{2}-h_{a}\right), 0 \leq h_{a} \leq \frac{3 l}{2} \cdot \frac{v}{t} & \frac{2}{3} \leq \alpha<\frac{4}{5} \\
t l, & \frac{3 l}{2}-\frac{v}{t} \leq h_{a} \leq \frac{l}{4} & \\
p_{a}=t l, & 0 \leq h_{a} \leq \frac{l}{4} & 0 \leq \alpha \leq \frac{2}{3}
\end{array}
$$$$
\frac{2}{3} \leq \alpha<\frac{4}{5}
$$

\section{DISCUSSION}

Our analysis can be neatly summarized for all possible values of $\alpha$, i.e. for all possible market sizes relative to the effective reservation price, by giving the local symmetric N-C equilibrium location (see equation (9) and Figure 8) and concomitant $\mathrm{N}-\mathrm{C}$ equilibrium price (see equation (10) and Figure 9) as a function of $\alpha$.

(9)

$$
\begin{aligned}
\frac{1}{4}, & 0 \leq \alpha \leq \frac{4}{5} \\
\frac{1}{3}\left(2-\frac{1}{\alpha}\right), & \frac{4}{5} \leq \alpha \leq \frac{8}{7} \\
\frac{h^{*}}{l}=\frac{1}{\alpha}-\frac{1}{2}, & \frac{8}{7} \leq \alpha \leq \frac{4}{3} \\
\frac{1}{4}, & \frac{4}{3} \leq \alpha \leq 2 \\
\in\left[\frac{1}{2 \alpha}, \frac{\alpha-1}{2 \alpha}\right], & 2 \leq \alpha<\infty
\end{aligned}
$$




$$
\begin{aligned}
\alpha v, & 0 \leq \alpha \leq \frac{4}{5} \\
\frac{2}{3}(2-\alpha) v, & \frac{4}{5} \leq \alpha \leq \frac{8}{7} \\
p^{*}=\frac{\alpha}{2} v, & \frac{8}{7} \leq \alpha \leq \frac{4}{3} \\
\left(1-\frac{\alpha}{4}\right) v, & \frac{4}{3} \leq \alpha \leq 2 \\
\frac{1}{2} v, & 2 \leq \alpha<\infty
\end{aligned}
$$

Our discussion in this section restricts attention to those situations in which the two firms actually compete with one another and cover the entire market $(\alpha \leq 2)$. The limits and possibilities of Hotelling's Principle of Minimum Differentiation for equilibrium locations are immediately clear from Figure 8: firms will never move closer together than a quarter of the length $l$ of the market $(=5 / 8-3 / 8)$, and never further apart than half the length of the market $(=3 / 4-1 / 4)$. In most cases the firms are located at the market quarters, and it would therefore be more appropriate to refer to the Principle of Intermediate Differentiation in the Hotelling setting. ${ }^{13}$ Firms have a tendency to move closer together to serve a larger market, but tend to retreat because of fiercer competition, or the threat of price wars.

The equilibrium price (see Figure 9) basically varies between one half and four-fifth of the reservation price. The fact that for $\alpha$ approaching zero the price depicted in Figure 9 also approaches zero is deceiving because for $\alpha \leq 4 / 5$ the equilibrium price equals $t l$ (see case 5), and is independent of

13 As noted before, AGT (1979 and 1983) already showed that the Principle of Minimum Differentiation is in general not valid. In quite different settings the Principle of Minimum Differentiation may hold, see e.g. De Palma, Ginsburgh, Papageorgiou and Thisse (1985), and Friedman and Thisse (1993). For quadratic transportation costs AGT (1979) derive a Principle of Maximum Differentiation, which however does not hold for finite reservation prices (Böckem, 1994). 
Figure 8 Equilibrium Locations

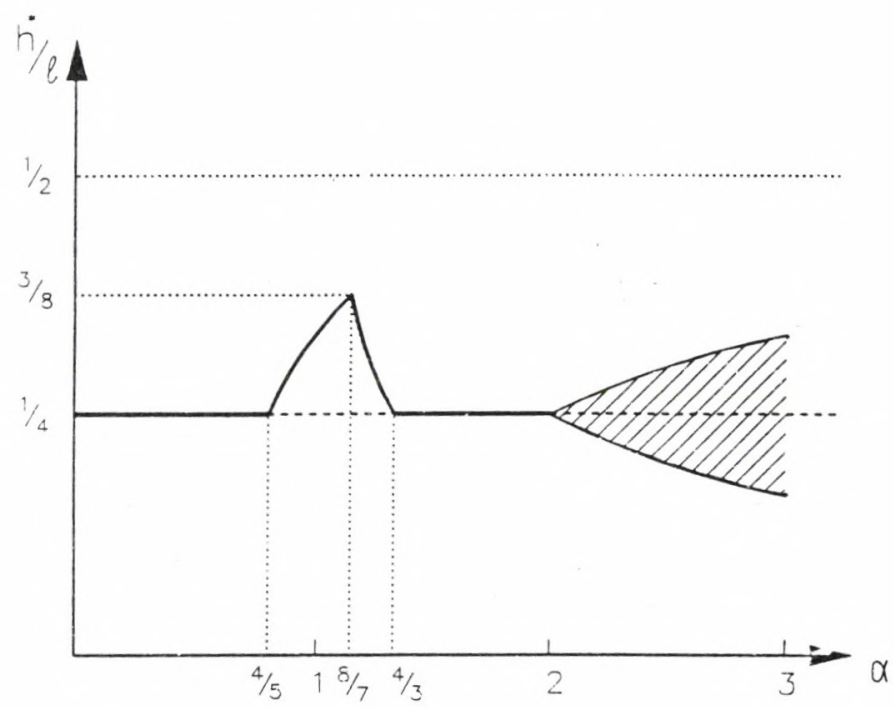

Figure 9 Equilibrium Prices

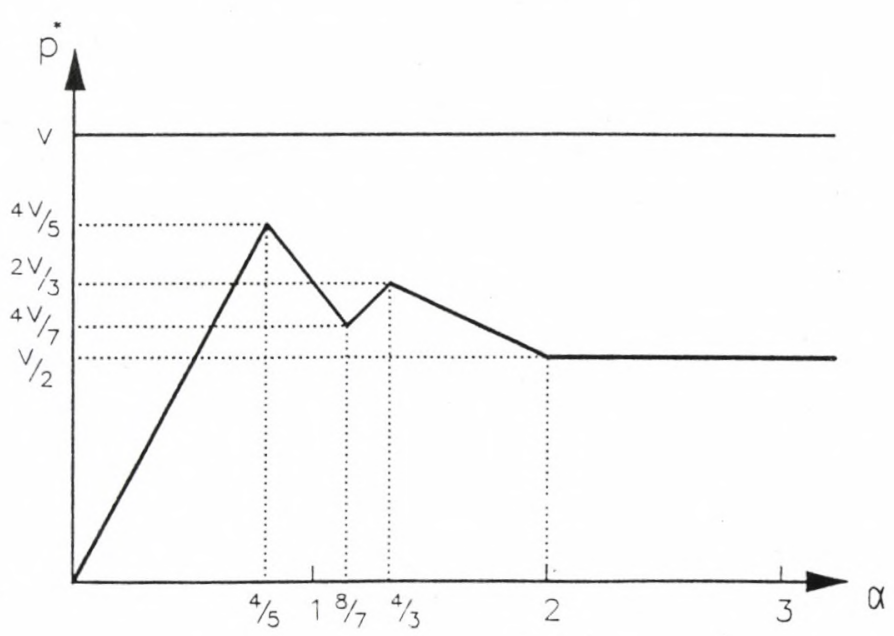


the reservation price (as long as the reservation price exceeds a threshold level).

Our analysis appears to be modest in two respects because we restrict attention to pure strategies and investigate only lccal symmetric equilibrium. Nonetheless, as argued below and in Section 2, we believe our analysis identifies an important location equilibrium.

The restriction of attention to pure strategies, building on AGT (1983), Economides (1984) and Friedman (1988), is partly based on ease of analysis and partly on a dislike of mixed strategies. As Martin (1993, p.274) puts it:

Real-world decisions abnut the locations of plants are not made randomly. Models that possess pure-strategy equilibria are more likely to yield a priori plausible hypotheses than models with mixed strategy equilibria.

Allowing for mixed strategies in the second stage of the game implies there is a $\mathrm{N}-\mathrm{C}$ price equilibrium for all possible locations (Dasgupta and Maskin (1986)). This may have implications for the location equilibrium, as Friedman (1988, p. 616) points out (read "location" in stead of "output level"):

I see no way to rule out the possibility that the equilibrium ... will be destroyed if mixed strategies are allowed. Perhaps a firm might increase its expected payoff by switching to an output level whose second-stage best play is a mixed-price choice. Analyzing this question appears extremely formidable.

Testimony of the fact that the analysis of 'this question' can indeed be 'extremely formidable' is given by the path-braking article of Osborne and Pitchik (1987) in a much simpler setting than Friedman (1988). Osborne and Pitchik analyze pure strategy in location in the first stage combined with mixed strategy in price in the second stage in the original Hotelling setting 
(i.e. case 5 with $\alpha \leq 2 / 3) .{ }^{14}$ They find an unique $\mathrm{N}-\mathrm{C}$ location equilibrium. The fact that this unique location equilibrium is symmetric to some extent justifies our decision to investigate only (neighbourhoods of) symmetric location equilibria. Using simulations Osborne and Pitchik estimate the $\mathrm{N}-\mathrm{C}$ location equilibrium, when allowing for mixed price strategies, to be at $h_{a}^{* *}=0.27 l$. Comparing this mixed price strategy location equilibrium with our pure price strategy location equilibrium $h_{a}^{*}=0.25 l$ (see case 5), suggest that firms have little, if any, incentive to enter the region in which pure strategies no longer exist.

First, the small difference between $h_{a}^{*}$ and $h_{a}^{* *}$ suggests that if firms have an incentive to enter the mixed strategy price region, this incentive is smail and quickly evaporates as firms move closer together. Second, Osborne and Pitchik show that, for symmetric locations, firms never charge a price exceeding the Hotelling price when allowing for mixed price strategies $(t l=1$ in their paper). This suggests that the prices one can derive here if no pure price strategy exists by ignoring the possibility of undercutting, are upper bounds for the mixed price strategies as well. If so, the equilibrium locations we identify here for values of $\alpha$ exceeding $8 / 7$ (cases 1, 2 and 3), which are determined by profit maximization considerations, will most likely be robust with respect to allowing for mixed strategies in prices.

Finally, we want to draw attention to the similarity between the Principle of Intermediate Differentiation for a line segment and the equilibrium location in a circular market. Indeed, Kats (1995) shows that for a circular market with a 'high enough' reservation price (i.e. firms compete and cover the entire market), the equilibrium location is equidistant spreading

\footnotetext{
${ }^{14}$ They also analyze mixed strategies in both location and price.
} 
along the circle with corresponding equilibrium price in pure strategies. On the other hand, the Principle of Intermediate Differentiation does not always hold for a linear market (cases 3 and 4). The difference in outcome arises because the geometry of the line enables a firm to have a protected 'hinterland', which gives an incentive to move closer to its opponent, while the geometry of a circle does not allow for this movement. ${ }^{15}$ If this hinterland is very profitable the possibility to undercut your opponent restores equidistant spacing (the hinterland then effectively disappears).

\section{CONCLUSIONS}

We analyze the effect of introducing a reservation price in the classic Hotelling (1929) model, in which firms first choose location and then are involved in Bertrand price competition. We restrict attention to pure strategies and neighbourhoods of symmetric locations. We complete the analysis of Economides (1984) for two monopolists and distinguish four more possibilities in which firms compete with one another. The equilibrium location of one of those four possibilities coincides with the Hotelling case analyzed by AGT (1979). Since the equilibrium location is usually at the market quarters (which maximizes the sum of consumer and producer surplus), it is more appropriate to speak of a Principle of Intermediate Differentiation than of a Principle of Minimum Differentiation. If firms compete at the equilibrium

${ }^{15}$ For the same reason Kats' argument on p. 4 on the limited profitability of undercutting, which builds on the symmetry of the circle, cannot be used for a market line. 
location (and thus cover the entire market) we show that firms will never be further apart than half the length of the market and never closer together than one quarter. 


\section{REFERENCES}

Böckem, S., 1994, "A Generalized Model of Horizontal Product Differentiation", Journal of Industrial Economics, Vol.XLII, No.3, p.287-98.

Dasgupta, P. and Maskin, E., 1986, "The Existence of Equilibrium in Discontinuous Economic Games, II: Applications", Review of Economic Studies, Vol.53, p.27-41.

d'Aspremont, C., Gabszewicz, J.J. and Thisse, J.-F., 1979, "On Hotelling's Stability in Competition", Econometrica, Vol.47, No.5, p.1145-50.

d'Aspremont, C., Gabszewicz, J.J. and Thisse, J.-F., 1983, "Product Differences and Prices", Economics Letters, Vol.11, p.19-23.

De Palma, A., Ginsburgh, V., Papageorgiou, Y.Y. and Thisse, J.-F., 1985, "The Principle of Minimum Differentiation Holds under Sufficient Heterogeneity", Econometrica, Vol.53, No.4, p.767-81.

Economides, N.S., 1984, "The Principle of Minimum Differentiation Revisited", European Economic Review, Vol.24, p.345-68.

Friedman, J.W., 1988, "On the Strategic Importance of Prices versus Quantities", Rand Journal of Economics, Vol. 19, p.607-22.

Harsanyi, J.C., 1975, "The Tracing Procedure: A Bayesian Approach to Defining a Solution for n-Person Non-Cooperative Games, International Journal of Game Theory, Vol.4, No.2, p.61-94.

Hotelling, H., 1929, "Stability in Competition", Economic Journal, Vol.39, p.41-57. 
Kats, A., 1995, "More on Hotelling's Stability in Competition", International Journal of Industrial Organization, Vol.13 p.89-93.

Lerner, A.P. and Singer, H.W., 1937, "Some Notes on Duopoly and Spatial Competition", Journal of Political Economy, Vol.45, p.145-86.

Martin, S., 1993, Advanced Industrial Economics, Oxford (UK) and Cambridge (USA): Blackwell Publishers.

Osborne, M.J. and Pitchik, C., 1987, "Equilibrium in Hotelling's Model of Spatial Competition", Econometrica, Vol.55, No.4, p.911-22.

Phlips, L. and Thisse, J.-F., 1982, "Spatial Competition and the Theory of Differentiated Markets: an Introduction", Journal of Industrial Economics, Vol.XXXI, p.1-9.

Salop, C.S., 1979, Monopolistic Competition with Outside Goods, Bell Journal of Ec-onomics, Vol.10, p.141-56.

Vickrey, W.S., 1964, Microstatics, New York and Burlingame: Harcourt, Brace, and World. 


\section{APPENDIX A}

In this appendix we derive the minimum distance between producers such that a pure strategy Nash-Cournot equilibrium in prices exists if some consumers at both corners of the market are not served.

\section{A1. LARGE MARKETS}

Let $d \leq 6 v / 7 t$ be the distance between the producers and parameterize this distance such that $d=\gamma v / t$. In the absence of undercutting the price charged, $p$, and the quantity sold, $q$, are given by (see Economides (1984)):

$$
\begin{aligned}
& p=\frac{1}{5}(2 v+t d)=\frac{2+\gamma}{5} v, \\
& q=\frac{d}{2}+\frac{v-p}{t}=\frac{3(2+\gamma)}{10} \frac{v}{t} .
\end{aligned}
$$

Hence, profits $\pi$ equal:

$$
\pi=p q=\frac{3(2+\gamma)^{2}}{50} \frac{v^{2}}{t}
$$

If a firm wants to undercut his opponent the price charged, $p_{u}$, and quantity sold, $q_{u}$, are:

$$
\begin{aligned}
& p_{u}=p-t d=\frac{2(1-2 \gamma)}{5} v, \\
& q_{u}=2 \frac{v-p_{u}}{t}=\frac{2(3+4 \gamma)}{5} \frac{v}{t} .
\end{aligned}
$$


Hence, profits from undercutting, $\pi_{u}$, are:

$$
\pi_{u}=p_{u} q_{u}=\frac{4(1-2 \gamma)(3+4 \gamma)}{25} \frac{v^{2}}{t} .
$$

The minimum distance between the two firms, $\alpha^{*} v / t$, follows from equating $\pi$ and $\pi_{u}$ and solving for $\gamma$. Call this solution $\alpha^{*}$, we get:

$$
\gamma=\frac{10 \sqrt{10}-14}{67} \equiv \alpha^{*} \approx 0.263
$$

If firms are located such that $\gamma<\alpha^{*}$, it becomes profitable for a firm to undercut his rival, i.e. no pure strategy Nash-Cournot equilibrium in prices exists.

Economides (1984) also derives a condition under which a 'competitive' N-C equilibrium exists. In particular it must be that (p.357, formula (8)):

$$
\frac{7}{6} \leq \frac{k}{y-x} \leq \frac{7+5 \sqrt{10}}{6}
$$

This must be the same as our condition for a 'competitive' equilibrium (see case 1$)$ :

$$
\frac{\alpha^{*} v}{t} \leq d \leq \frac{6 v}{7 t}
$$

Realizing that $y-x$ is the distance between the two firms ( $d$ in our notation), that $k$ is Economides' reservation price, and that Economides sets unit transport costs at one $(t=1)$, it must be that

$$
\frac{1}{\alpha^{*}}=\frac{7+5 \sqrt{10}}{6}
$$

Now note that: 


$$
\begin{aligned}
\frac{1}{\alpha^{*}} & =\frac{67}{10 \sqrt{10}-14}=\frac{67}{6(10 \sqrt{10} / 6-7 / 3)}=\frac{70 \sqrt{10} / 6+831 / 3-70 \sqrt{10} / 6-11}{6(10 \sqrt{10} / 6-7 / 3)} \\
& =\frac{(10 \sqrt{10} / 6-7 / 3)(5 \sqrt{10}+7)}{6(10 \sqrt{10} / 6-7 / 3)}=\frac{5 \sqrt{10}+7}{6}
\end{aligned}
$$

\section{A2. SOMEWHAT SMALLER MARKETS}

A slight complication in the derivation of the minimum distance between firms arises if the market becomes 'somewhat' smaller. The problem occurs because the discussion in Appendix A1 assumes that a firm can sell quantity $q_{u}$ if it charges price $p_{u}$ when it undercuts its opponent. However, if $h<q_{u} / 2$, this is not possible (see Figure A1). Therefore, consider now a symmetric location $h$ such that when undercutting $q_{u} / 2>h$, given that both firms charge 'competitive' prices in the Economides (1984) sense.

Let $l=\alpha v / t$. The objective is to find a scalar $\beta$, implicitly given by $h=\beta v / t$, such that profits from undercutting are equal to regular profits. In the absence of undercutting, price $p$, quantity $q$ and profits $\pi$ equal:

$$
\begin{aligned}
& p=\frac{2}{5}\left[v+t\left(\frac{l}{2}-h\right)\right]=\frac{1}{5}[(2+\alpha)-2 \beta] v, \\
& q=\left[\left(\frac{l}{2}-h\right)+\frac{v-p}{t}\right]=\left[\frac{6+3 \alpha}{10}-\frac{3}{5} \beta\right] \frac{v}{t}, \\
& \pi=\frac{1}{25}[(2+\alpha)-2 \beta]\left[\frac{6+3 \alpha}{2}-3 \beta\right] \frac{v^{2}}{t} .
\end{aligned}
$$

If a firm undercuts his rival, he charges price $p_{u}$, sells quantity $q_{u}$, and earns profits $\pi_{u}$, all respectively given by (see also Figure A1): 
Figure A1 Undercutting in a 'somewhat smaller' market

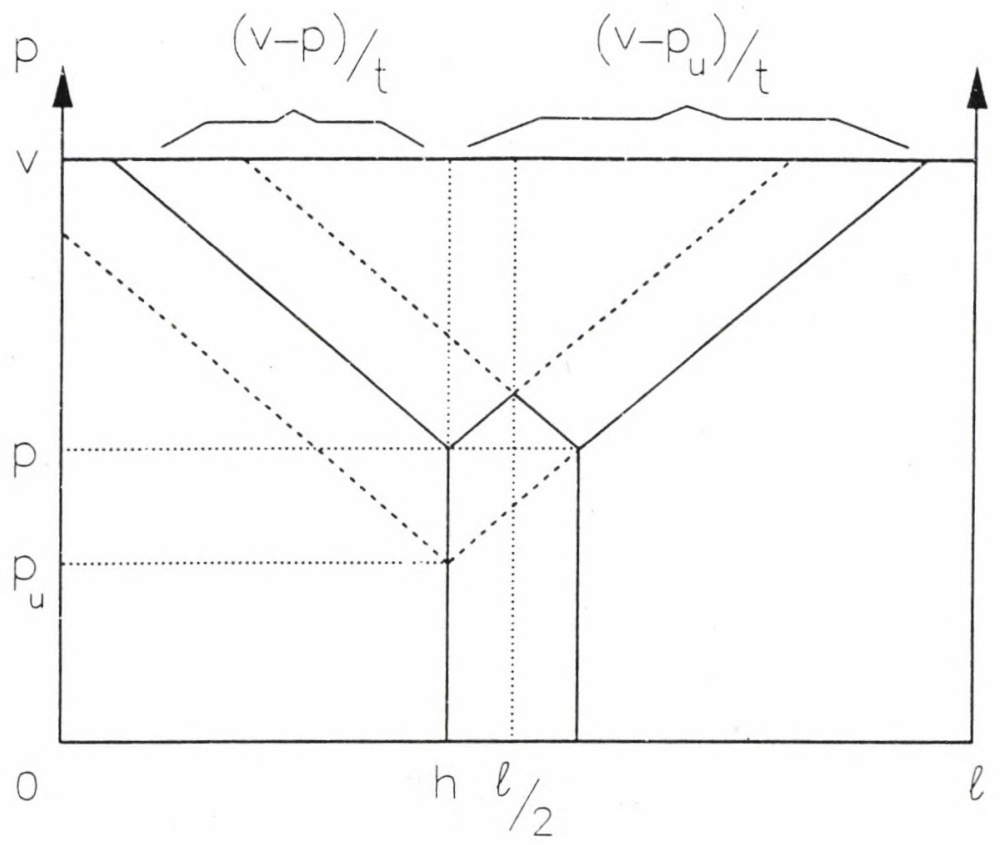

$$
\begin{aligned}
& p_{u}=p-2 t\left(\frac{l}{2}-h\right)=\frac{2}{5}[(1-2 \alpha)+4 \beta] v, \\
& q_{u}=\frac{l}{2}+\frac{v-p}{t}+\left(\frac{l}{2}-h\right)=\frac{1}{5}[(3+4 \alpha)-3 \beta] \frac{v}{t}, \\
& \pi_{u}=\frac{2}{25}[(1-2 \alpha)+4 \beta][(3+4 \alpha)-3 \beta] \frac{v^{2}}{t} .
\end{aligned}
$$


Setting $\pi=\pi_{u}$ and solving for $\beta$ as a function of $\alpha$ gives us:

$$
\beta(\alpha)=\frac{3+5 \alpha-\sqrt{\alpha^{2}+18 \alpha+9}}{6} .
$$

The situation of a 'somewhat' smaller market occurs if $h<\left(v-\left.p_{u}\right|_{\alpha=\alpha^{*}}\right) / t$ or $\left(\alpha, v / t-\left.d\right|_{\alpha=x}\right) / 2<\left(v-\left.p_{u}\right|_{\alpha=\alpha^{*}}\right) / t$. This leads to:

$$
\alpha<\left(6+13 \alpha^{*}\right) / 5 \approx 1.884 \text {. }
$$

Note that for $\alpha=\left(6+13 \alpha^{*}\right) / 5$ it follows that $q_{u} / 2=h$ for $h=l / 2-\alpha^{*} v / 2 t$, i.e. the analyses of Appendix A1 and A2 coincide.

\section{APPENDIX B}

This appendix derives the $\mathrm{N}-\mathrm{C}$ equilibrium prices depicted in Figure 4 in the text. Clearly, this is the analog of the 'touching' equilibrium analyzed by Economides (1984) when consumers in the corner of the market are served rather than not served. For the range of locations that gives rise to this type of 'touching' equilibrium a continuum of $\mathrm{N}-\mathrm{C}$ equilibrium prices exists as a result of the kinked profit function. We will therefore follow Economides, who appeals to symmetry and Harsanyi's (1975) 'tracing procedure', by selecting equal N-C equilibrium prices for both firms. Let $h_{a}, h_{b} \in[0, l / 4]$. We want to show under which conditions $p_{a}^{*}=p_{b}^{*}=v-t\left(l-h_{a}-h_{b}\right) / 2$ in the neighbourhood of symmetric equilibria. First, note that if these are the N-C equilibrium prices $\pi_{a}^{*}\left(h_{a}, h_{b}\right)=\left(v-t\left(l-h_{a}-h_{b}\right) / 2\right)\left(h_{a}+\left(l-h_{a}-h_{b}\right) / 2\right)$ are the resulting profits for firm $a$, while for firm $b$ these are in that case given by $\pi_{b}^{*}\left(h_{a}, h_{b}\right)=\left(v-t\left(l-h_{a}-h_{b}\right) / 2\right)\left(h_{b}+\left(l-h_{a}-h_{b}\right) / 2\right)$. Consequently, $\partial \pi_{a}^{*}\left(h_{a}, h_{b}\right) / \partial h_{a}>0$ and $\partial \pi_{b}^{*}\left(h_{a}, h_{b}\right) / \partial h_{b}>0$, indicating that firms have an incentive to move closer together. Second, note that it is not possible to undercut your opponent as this requires a negative price. Third, a price increase reduces profits for $h_{a}=h_{b}$ if $h_{a} \geq l-v / t$. This condition is operative in case 3 and subcase 4.1 in the text. Fourth, a price cut reduces profits for $h_{a}=h_{b}$ if $h_{a} \leq 3 l / 2-v / t$. This condition marks transition to the Hotelling price (see AGT) and is operative in subcase 5.1. 


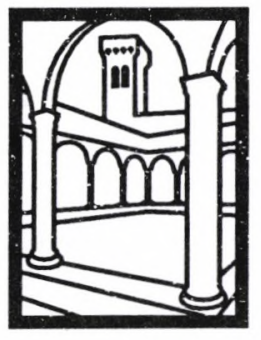

EUI

WORKING

PAPERS

EUI Working Papers are published and distributed by the

European University Institute, Florence

Copies can be obtained free of charge

- depending on the availability of stocks - from:

The Publications Officer

European University Institute

Badia Fiesolana

I-50016 San Domenico di Fiesole (FI)

Italy 


\section{圆}

\section{Publications of the European University Institute}

\section{Department of Economics Working Paper Series}

To

Department of Economics WP

European University Institute

Badia Fiesolana

I-50016 San Domenico di Fiesole (FI)

E-mail: publish@datacomm.iue.it

Italy

From Name

Address.

(Please print)

$\square$ Please enter/confirm my name on EUI Economics Dept. Mailing List

$\square$ Please send me a complete list of EUI Working Papers

$\square$ Please send me a complete list of EUI book publications

$\square$ Please send me the EUI brochure Academic Year 1995/96

Please send me the following EUI ECO Working Paper(s):

No, Author

Title:

No, Author

Title:

No, Author

Title:

No, Author

Title:

Date

Signature 


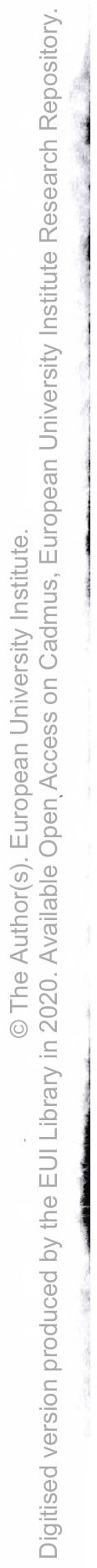




\section{Working Papers of the Department of Economics Published since 1993}

ECO No. 93/1

Carlo GRILLENZONI

Forecasting Unstable and Non-Stationary

Time Series

ECO No. 93/2

Carlo GRILLENZONI

Multilinear Models for Nonlinear Time

Series

ECO No. $93 / 3$

Ronald M. HARSTAD/Louis PHLIPS

Futures Market Contracting When You

Don't Know Who the Optimists Are

ECO No. 93/4

Alan KIRMAN/Louis PHLIPS

Empirical Studies of Product Markets

ECO No. 93/5

Grayham E. MIZON

Empirical Analysis of Time Series:

Illustrations with Simulated Data

ECO No. 93/6

Tilman EHRBECK

Optimally Combining Individual

Forecasts From Panel Data

ECO NO. 93/7

Víctor GÓMEZ/Agustín MARAVALL

Initializing the Kalman Filter with

Incompletely Specified Initial Conditions

ECO No. 93/8

Frederic PALOMINO

Informed Speculation: Small Markets

Against Large Markets

ECO NO. 93/9

Stephen MARTIN

Beyond Prices Versus Quantities

ECO No. 93/10

José María LABEAGA/Angel LÓPEZ

A Flexible Demand System and VAT

Simulations from Spanish Microdata

ECO No. 93/11

Maozu LU/Grayham E. MIZON

The Encompassing Principle and

Specification Tests
ECO No. 93/12

Louis PHLIPS/Peter MØLLGAARD

Oil Stocks as a Squeeze Preventing

Mechanism: Is Self-Regulation Possible?

ECO No. 93/13

Pieter HASEKAMP

Disinflation Policy and Credibility: The

Role of Conventions

ECO No. 93/14

Louis PHLIPS

Price Leadership and Conscious

Parallelism: A Survey

ECO No. 93/15

Agustín MARAVALL

Short-Term Analysis of Macroeconomic Time Series *

ECO No. 93/16

Philip Hans FRANSES/Niels

HALDRUP

The Effects of Additive Outliers on Tests for Unit Roots and Cointegration

ECO No. 93/17

Fabio CANOVA/Jane MARRINAN

Predicting Excess Returns in Financial Markets

ECO No. 93/18

Iñigo HERGUERA

Exchange Rate Fluctuations, Market

Structure and the Pass-through

Relationship

ECO No. 93/19

Agustín MARAVALL

Use and Misuse of Unobserved

Components in Economic Forecasting

ECO No. 93/20

Torben HOLVAD/Jens Leth

HOUGAARD

Measuring Technical Input Efficiency for Similar Production Units:

A Survey of the Non-Parametric

Approach 
ECO No. 93/21

Stephen MARTIN/Louis PHLIPS

Product Differentiation, Market Structure and Exchange Rate Passthrough

ECO No 93/22

F. CANOVA/M. FINN/A. R. PAGAN

Evaluating a Real Business Cycle Model

ECO No 93/23

Fabio CANOVA

Statistical Inference in Calibrated Models

ECO No 93/24

Gilles TEYSSIËRE

Matching Processes in the Labour Market in Marseilles. An Econometric Study

ECO No 93/25

Fabio CANOVA

Sources and Propagation of International Business Cycles: Common Shocks or Transmission?

ECO No. 93/26

Marco BECHT/Carlos RAMÍREZ

Financial Capitalism in Pre-World War I

Germany: The Role of the Universal

Banks in the Financing of German

Mining Companies 1906-1912

ECO No. 93/27

Isabelle MARET

Two Parametric Models of Demand,

Structure of Market Demand from

Heterogeneity

ECO No. 93/28

Stephen MARTIN

Vertical Product Differentiation, Intraindustry Trade, and Infant Industry

Protection

ECO No. 93/29

J. Humberto LOPEZ

Testing for Unit Roots with the k-th

Autocorrelation Coefficient

ECO No. 93/30

Paola VALBONESI

Modelling Interactions Between State and

Private Sector in a "Previously" Centrally

Planned Economy
ECO No. 93/31

Enrique ALBEROLA ILA/J. Humberto

LOPEZ/Vicente ORTS RIOS

An Application of the Kalman Filter to

the Spanish Experience in a Target Zone (1989-92)

ECO No. 93i32

Fabio CANOVA/Morten O. RAVN

International Consumption Risk Sharing

ECO No. 93/33

Morten Overgaard RAVN

International Business Cycles: How

much can Standard Theory Account for?

ECO No. 93/34

Agustín MARAVALL

Unobserved Components in Economic

Time Series *

ECO No. 93/35

Sheila MARNIE/John

MICKLEWRIGHT

Poverty in Pre-Reform Uzbekis'an:

What do Official Data Really Reveal? *

ECO No. 93/36

Torben HOLVAD/Jens Leth

HOUGAARD

Measuring Technical Input Efficiency for

Similar Production Units:

80 Danish Hospitals

ECO No. 93/37

Grayham E. MIZON

A Simple Message for Autocorrelation

Correctors: DON'T

ECO No. 93/38

Barbara BOEHNLEIN

The Impact of Product Differentiation on

Collusive Equilibria and Multimarket

Contact

ECO No. 93/39

H. Peter MØLlGAARD

Bargaining and Efficiency in a

Speculative Forward Market

米料米 
ECO No. 94/1

Robert WALDMANN

Cooperatives With Privately Optimal

Price Indexed Debt Increase Membership

When Demand Increases

ECO No. 94/2

Tilman EHRBECK/Robert

WALDMANN

Can Forecasters' Motives Explain

Rejection of the Rational Expectations

Hypothesis?

ECO No. 94/3

Alessandra PELLONI

Public Policy in a Two Sector Model of

Endogenous Growth *

ECO No. $94 / 4$

David F. HENDRY

On the Interactions of Unit Roots and

Exogeneity

ECO No. 94/5

Bernadette GOVAERTS/David F. HENDRY/Jean-François RICHARD

Encompassing in Stationary Linear

Dynamic Models

ECO No. 94/6

Luigi ERMINI/Dongkoo CHANG

Testing the Joint Hypothesis of Rationality and Neutrality under Seasonal Cointegration: The Case of Korea

ECO No. 94/7

Gabriele FIORENTINV/Agustín

MARAVALL

Unobserved Components in ARCH

Models: An Application to Seasonal

Adjustment *

ECO No. 94/8

Niels HALDRUP/Mark SALMON

Polynomially Cointegrated Systems and

their Representations: A Synthesis

ECO No. 94/9

Mariusz TAMBORSKI

Currency Option Pricing with Stochastic Interest Rates and Transaction Costs:

A Theoretical Model

ECO No. $94 / 10$

Mariusz TAMBORSKI

Are Standard Deviations Implied in

Currency Option Prices Good Predictors

of Future Exchange Rate Volatility?
ECO No. 94/11

John MICKLEWRIGHT/Gyula NAGY

How Does the Hungarian Unemploy-

ment Insurance System Really Work? *

ECO No. 94/12

Frank CRITCHLEY/Paul

MARRIOTT/Mark SALMON

An Elementary Account of Amari's

Expected Geometry

ECO No. 94/13

Domenico Junior MARCHETTI

Procyclical Productivity, Externalities and Labor Hoarding: A Reexamination of Evidence from U.S. Manufacturing

ECO No. 94/14

Giovanni NERO

A Structural Model of Intra-European

Airline Competition

ECO No. 94/15

Stephen MARTIN

Oligopoly Limit Pricing: Strategic

Substitutes, Strategic Complements

ECO No. 94/16

Ed HOPKINS

Learning and Evolution in a

Heterogeneous Population

ECO No. 94/17

Berthold HERRENDORF

Seigniorage, Optimal Taxation, and Time

Consistency: A Review

ECO No. 94/18

Frederic PALOMINO

Noise Trading in Small Markets *

ECO No. 94/19

Alexander SCHRADER

Vertical Foreclosure, Tax Spinning and

Oil Taxation in Oligopoly

ECO No. 94/20

Andrzej BANIAK/Louis PHLIPS

La Pléiade and Exchange Rate Pass-

Through

ECO No. 94/21

Mark SALMON

Bounded Rationality and Learning;

Procedural Learning 
ECO No. $94 / 22$

Isabelle MARET

Heterogeneity and Dynamics of

Temporary Equilibria: Short-Run Versus

Long-Run Stability

ECO No. 94/23

Nikolaos GEORGANTZIS

Short-Run and Long-Run Cournot

Equilibria in Multiproduct Industries

ECO No. 94/24

Alexander SCHRADER

Vertical Mergers and Market Foreclosure:

Comment

ECO No. 94/25

Jeroen HINLOOPEN

Subsidising Cooperative and Non-

Cooperative R\&D in Duopoly with

Spillovers

ECO No. 94/26

Debora DI GIOACCHINO

The Evolution of Cooperation:

Robustness to Mistakes and Mutation

ECO No. 94/27

Kristina KOSTIAL

The Role of the Signal-Noise Ratio in

Cointegrated Systems

ECO No. 94/28

Agustín MARAVALL/Víctor GÓMEZ

Program SEATS "Signal Extraction in

ARIMA Time Series" - Instructions for the User

ECO No. 94/29

Luigi ERMINI

A Discrete-Time Consumption-CAP

Model under Durability of Goods, Habit

Formation and Temporal Aggregation

ECO No. $94 / 30$

Debora DI GIOACCHINO

Learning to Drink Beer by Mistake

ECO No. 94/31

Víctor GOOMEZ/Agustín MARAVALL

Program TRAMO "Time Series

Regression with ARIMA Noise, Missing

Observations, and Outliers" -

Instructions for the User
ECO No. 94/32

Ákos VALENTINYI

How Financial Development and

Inflation may Affect Growth

ECO No. $94 / 33$

Stephen MARTIN

European Community Food Processing Industries

ECO No. 94/34

Agustín MARAVALU/Christophe

PLANAS

Estimation Error and the Specification of Unobserved Component Models

ECO No. 94/35

Robbin HERRING

The "Divergent Beliefs" Hypothesis and the "Contract Zone" in Final Offer Arbitration

ECO No. 94/36

Robbin HERRING

Hiring Quality Labour

ECO No. 94/37

Angel J. UBIDE

Is there Consumption Risk Sharing in the EEC?

ECO No. 94/38

Berthold HERRENDORF

Credible Purchases of Credibility

Through Exchange Rate Pegging:

An Optimal Taxation Framework

ECO No. 94/39

Enrique ALBEROLA ILA

How Long Can a Honeymoon Last?

Institutional and Fundamental Beliefs in

the Collapse of a Target Zone

ECO No. 94/40

Robert WALDMANN

Inequality, Economic Growth and the

Debt Crisis

ECO No. 94/41

John MICKLEWRIGHT/

Gyula NAGY

Flows to and from Insured

Unemployment in Hungary 
ECO No. 94/42

Barbara BOEHNLEIN

The Soda-ash Market in Europe:

Collusive and Competitive Equilibria

With and Without Foreign Entry

ECO No. 94/43

Hans-Theo NORMANN

Stackelberg Warfare as an Equilibrium

Choice in a Game with Reputation Effects

ECO No. 94/44

Giorgio CALZOLARI/Gabriele

FIORENTINI

Conditional Heteroskedasticity in

Nonlinear Simultaneous Equations

ECO No. 94/45

Frank CRITCHLEY/Paul MARRIOTT/

Mark SALMON

On the Differential Geometry of the Wald

Test with Nonlinear Restrictions

ECO No. 94/46

Renzo G. AVESANI/Giampiero M.

GALLO/Mark SALMON

On the Evolution of Credibility and

Flexible Exchange Rate Target Zones

米米米

ECO No. 95/1

Paul PEZANIS-CHRISTOU

Experimental Results in Asymmetric

Auctions - The 'Low-Ball' Effect

ECO No. 95/2

Jeroen HINLOOPEN/Rien

WAGENVOORT

Robust Estimation: An Example

ECO No. 95/3

Giampiero M. GALLO/Barbara PACINI

Risk-related Asymmetries in Foreign

Exchange Markets

ECO No. 95/4

Santanu ROY/Rien WAGENVOORT

Risk Preference and Indirect Utility in

Portfolio Choice Problems

ECO No. 95/5

Giovanni NERO

Third Package and Noncooperative

Collusion in the European Airline

Industry
ECO No. 95/6

Renzo G. AVESANU/Giampiero M.

GALLO/Mark SALMON

On the Nature of Commitment in Flexible

Target Zones and the Measurement of

Credibility: The 1993 ERM Crisis

ECO No. 95/7

John MICKLEWRIGHT/Gyula NAGY

Unemployment Insurance and Incentives in Hungary

ECO No. 95/8

Kristina KOSTIAL

The Fully Modified OLS Estimator as a

Systern Estimator: A Monte-Carlo

Analysis

ECO No. 95/9

Günther REHME

Redistribution, Wealth Tax Competition and Capital Flight in Growing

Economies

ECO No. 95/10

Grayham E. MIZON

Progressive Modelling of

Macroeconomic Time Series: The LSE

Methodology

ECO No. 95/11

Pierre CAHUC/Hubert KEMPF

Alternative Time Patterns of Decisions and Dynamic Strategic Interactions

ECO No. 95/12

Tito BOERI

Is Job Turnover Countercyclical?

ECO No. 95/13

Luisa ZANFORLIN

Growth Effects from Trade and

Technology

ECO No. 95/14

Miguel JIMÉNEZ/Domenico

MARCHETTI, jr.

Thick-Market Externalities in U.S.

Manufacturing: A Dynamic Study with

Panel Data

ECO No. 95/15

Berthold HERRENDORF

Exchange Rate Pegging, Transparency, and Imports of Credibility 
ECO No. 95/16

Günther REHME

Redistribution, Income cum Investment

Subsidy Tax Competition and Capital

Flight in Growing Economies

ECO No. 95/17

Tito BOERI/Stefano SCARPETTA

Regional Dimensions of Uncmployment

in Central and Eastern Europe and Social

Barriers to Restructuring

ECO No. 95/18

Bernhard WINKLER

Reputation for EMU - An Economic

Defence of the Maastricht Criteria

ECO No. 95/19

Ed HOPKINS

Learning, Matching and Aggregation

ECO No. 95/20

Dorte VERNER

Can the Variables in an Extended Solow

Model be Treated as Exogenous?

Learning from International Comparisons

Across Decades

ECO No. 95/21

Enrique ALBEROLA-ILA

Optimal Exchange Rate Targets and

Macroeconomic Stabilization

ECO No. 95/22

Robert WALDMANN

Predicting the Signs of Forecast Errors

ECO No. 95/23

Robert WALDMANN

The Infant Mortality Rate is Higher

where the Rich are Richer

ECO No. 95/24

Michael J. ARTIS/Zenon G.

KONTOLEMIS/Denise R. OSBORN

Classical Business Cycles for G7 and

European Countries

ECO No. 95/25

Jeroen HINLOOPEN/Charles VAN

MARREWIJK

On the Limits and Possibilities of the

Principle of Minimum Differentiation 
(1)

은 등

யี

(1)

흐음

兵

<

동

(2) ก

$\subseteq$

त्ष 


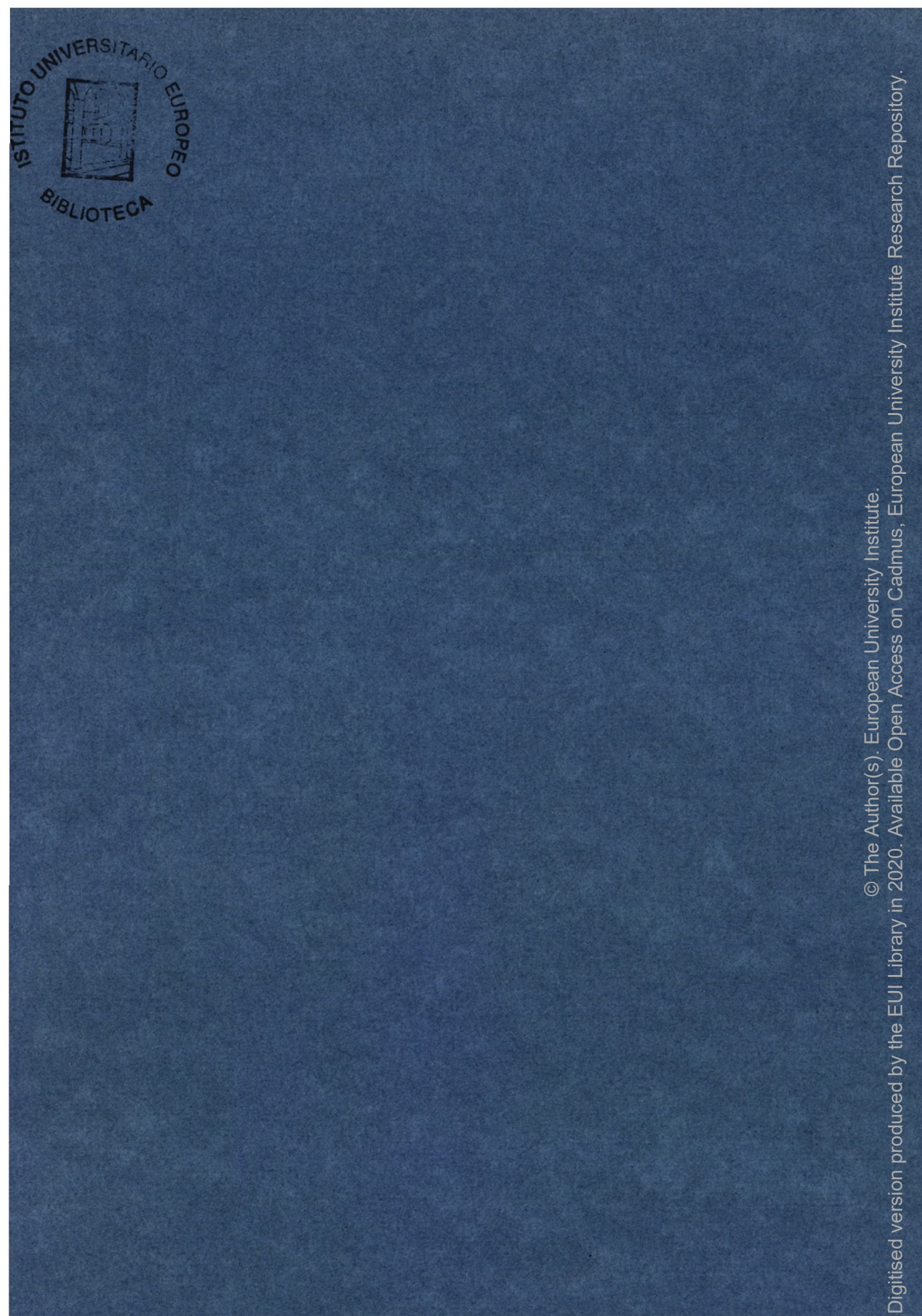

